\title{
APLIKASI OPTIMASI BAHAN CETAKAN DENGAN METODE BRANCH \& BOUND PADA PERCETAKAN CENTRAL GRAFINDO
}

\author{
Edy Andersen, Halim Agung \\ Program Studi Teknik Informatika \\ Universitas Bunda Mulia \\ Jl. Lodan Raya No.2 Jakarta \\ edyandersen@gmail.com, hagung@bundamulia.ac.id
}

\begin{abstract}
Abstrak
Percetakan merupakan teknologi atau seni yang memproduksi salinan dari sebuah image dan desain dengan sangat cepat, seperti kata atau gambar di atas kertas atau bahan baku. Central Grafindo merupakan salah satu perusahaan percetakan yang telah beroperasi di Jakarta sejak tahun 2010. Dalam hal pelayanan pada pelanggan, Central Grafindo memiliki beragam permasalahan. Dimana saat ini setiap customer yang melakukan permintaan rincian harga atas kebutuhan mereka, dilakukan perhitungan secara manual sehingga di rasa sangat memakan waktu dan ke akuratan dalam perhitungan tersebut tidak selalu benar. Selain itu, setiap penghitungan area cetak harus di sesuaikan dengan bahan masih di lakukan secara manual sehingga waktu sangat terbuang banyak dalam proses perhitungan tersebut. Algoritma yang digunakan pada penelitian ini adalah Metode Branch \& Bound yang dimana sistem kerjanya dilakukan dengan memecah persoalan ke dalam beberapa kondisi yang telah di atur sehingga dapat menghasilkan nilai Optimum area cetak. Hasil penelitian yang di dapatkan adalah aplikasi simulasi area cetak dan perhitungan harga dapat di implementasikan pada Central Grafindo berdasarkan hasil pengujian dengan Metode Branch \& Bound maka di dapat hasil yang cukup memuaskan dengan persentase keberhasilan mencapai 100\% dari 50 kali percobaan.
\end{abstract}

Kata kunci:

Area Cetak, Branch \& Bound, Bahan, Cetakan

\section{Abstract}

Printing is a technology or art that produces copies of an image and design very quickly, such as words or images on paper or raw materials. Central Grafindo is one printing company that has been operating in Jakarta since 2010. In terms of customer service, Central Grafindo has various problems. Where now every customer who requests price details of their needs, done manually calculations so that in very time consuming sense and to accuracy in the calculation is not always true. In addition, any calculation of the print area should be adjusted with the material still done manually so that time is very much wasted in the calculation process. The algorithm used in this research is Branch \& Bound Method where its work system is done by breaking the problem into some condition that has been set so that it can yield optimum value of print area. The results obtained are the application of print area simulation and price calculation can be implemented on Central Grafindo based on the test results with Branch \& Bound Method then in the results can be quite satisfactory with the percentage of success reached $100 \%$ of 50 experiments.

Keywords:

Print Area, Branch \& Bound, Materials, Prints.

\section{Pendahuluan}

Dalam hal pelayanan pada pelanggan, Central Grafindo memiliki beragam permasalahan. Di mana saat ini setiap customer yang melakukan permintaan rincian harga atas kebutuhan mereka, dilakukan perhitungan secara manual sehingga di rasa sangat memakan waktu dan keakuratan dalam perhitungan tersebut tidak selalu benar. Selain itu, setiap penghitungan area cetak harus di sesuaikan dengan bahan masih di lakukan secara manual sehingga 
waktu sangat terbuang banyak dalam proses perhitungan tersebut.

Rumusan masalah yang akan dibahas pada penelitian ini adalah Bagaimana mengoptimasi area bahan cetakan sehingga dapat mendapat hasil kuantitas yang optimal atau maksimal. Oleh karena itu, penelitian ini menerapkan metode Branch \& Bound pada aplikasi proses perhitungan bahan cetakan.

Tujuan penelitian ini untuk menghasilkan aplikasi yang dapat mengukur dan membandingkan ukuran bahan cetakan dan bahan baku serta mendapatkan nilai optimal bahan yang akan berimplikasi pada penentuan harga jual sebuah proyek cetakan.

\section{KAJIAN LITERATUR}

\section{II.1 Penelitian Terdahulu}

Berdasarkan hasil telah terhadap penelitian yang berkaitan dengan metode Branch \& Bound, terdapat beberapa hasil penelitian yang dapat dijadikan dasar acuan kajian ini, antara lain:

1. (Suryawan, Tastrawati, Sari, 2016) yang berjudul "Penerapan Branch and Bound algorithm dalam optimalisasi produksi roti“" yang memberikan keuntungan perusahaan Ramadhan Bakery sebelumnya dengan asumsi semua produksi habis terjual adalah Rp. 954.504. Dengan demikian terjadi peningkatan keuntungan sebesar $25.2 \%$ melalui perhitungan dengan menerapkan Branch and Bound Algorithm.

2. (Mangngenre, Rapi, Flannery, 2014) yang berjudul "Penjadwalan produksi dengan metode branch \& bound pada PT. XYZ" yang menyatakan bahwa dari hasil pengolahan data waktu proses enam job dengan lima tahap permesinan dari PT. XYZ dengan metode branch and bound didapatkan solusi optimal untuk penjadwalan produksi enam produk dengan nilai makespan sebesar 263.42 menit.

3. (Rosa, Suhartono, Wibawa, 2013) yang berjudul "Penentuan jalur terpendek pada pelayanan agen travel khusus pengantaran wilayah semarang berbasis SIG dengan algoritma branch and bound" yang memberikan keuntungan pada agen travel dalam pengantaran penumpang untuk penentuan rute terpendek yang berdampak pada penghematan biaya transportasi dan memperpendek waktu perjalanan.

4. (Hayati, 2010) yang berjudul "Aplikasi algoritma branch and bound untuk menyelesaikan integer programming" dengan algoritma ini tetap menghitung kemungkinan solusi dengan tipe variabel bilangan real walaupun pada akhirnya kemungkinan solusi ini tidak akan dipertimbangkan

5. (Retnawati, Suswaini, Hayaty, 2012) yang berjudul "Optimasi produk dan keuntungan pada industri kerupuk dengan metode linier programming simpleks dan branch and bound CV. Kyria Rezeki” Berdasarkan dari penelitian yang dilakukan dengan menggunakan metode linear programming simpleks dan branch and bound didapatkan bahwa perencanaan produksi dapat dilakukan dengan optimal dan dapat memaksimalkan keuntungan.

\section{II.2 Metode Branch \& Bound (B\&B)}

Metode Branch and Bound merupakan suatu metode pencarian di dalam ruang solusi secara sistematis. Tiap simpul yang dibandingkan akan diberikan nilai (value). Untuk mempercepat pencarian solusi maka simpul berikut yang diekspansi tidak berdasarkan urutan pembangkitnya tetapi berdasarkan value yang dimiliki oleh simpulsimpul tersebut (Riyani, 2013)

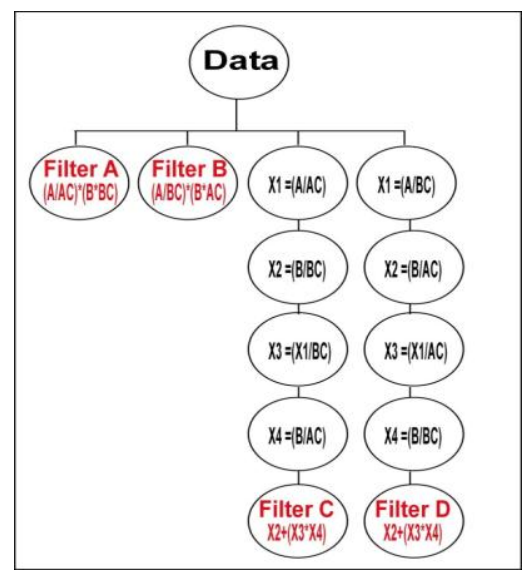

Gambar 1 Metode Branch \& Bound

Skema Umum atau langkah-langkah pencarian solusi dengan menggunakan Metode Branch And Bound: 
1. Simpul akar dimasukan ke dalam antrian Q. jika simpul akar adalah simpul solusi, maka solusi telah ditemukan dan pencarian berhenti.

2. Antrian $\mathrm{Q}$ diidentifikasi:

a. Jika antrian Q kosong, maka solusi tidak ada dan pencarian berhenti.

\section{III.ANALISIS DAN PERANCANGAN}

Peneliti menggunakan beberapa tahapan yang harus dilakukan untuk menggambarkan sistem sebelum membuat aplikasi yang menggunakan metode Branch \& Bound. Metode yang digunakan dalam penelitian ini adalah metode Waterfall (Bassil, 2012).

\section{III.1 Analisis Kebutuhan Fungsional}

Kebutuhan fungsional yang diperlukan sistem sebagai berikut:

1. Sistem dapat menyelesaikan perhitungan optimasi area cetak dengan menggunakan metode Branch \& Bound.

2. Sistem dapat menyelesaikan perhitungan optimasi area cetak dengan cepat dibandingkan apabila menghitung manual oleh manusia.

3. Sistem dapat mengurangi kesalahan perhitungan pada simulasi area cetak dan simulasi harga atau biaya sehingga mendapat nilai yang akurat.

\section{III.2 Entity Relationship Diagram (ERD)}

ERD yang digunakan pada Central Grafindo dalam menentukan optimasi dan harga, sebagai berikut:

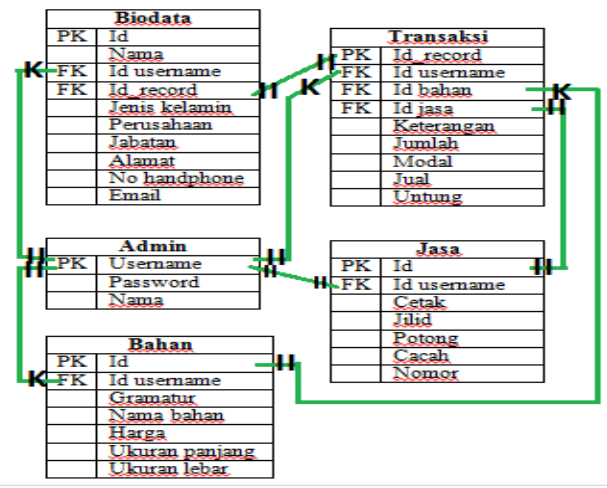

Gambar 2. ERD Aplikasi b. Jika antrian Q tidak kosong, maka dipilih dari antrian $\mathrm{Q}$ yang di filter dan simpul $\mathrm{i}$ yang mempunyai nilai paling besar.

c. Jika terdapat beberapa nilai simpul i yang sama maka akan dipilih nilai secara sembarang.

\section{Hasil Penelitian dan Pembahasan}

Pada Aplikasi yang sudah mengimplementasikan algoritma Branch \& Bound, Pengguna dapat menjalankan aplikasi dan membandingkan bahan yang sesuai dengan keinginan user. Pengguna membandingkan bahan pada form NCR seperti pada gambar 3:

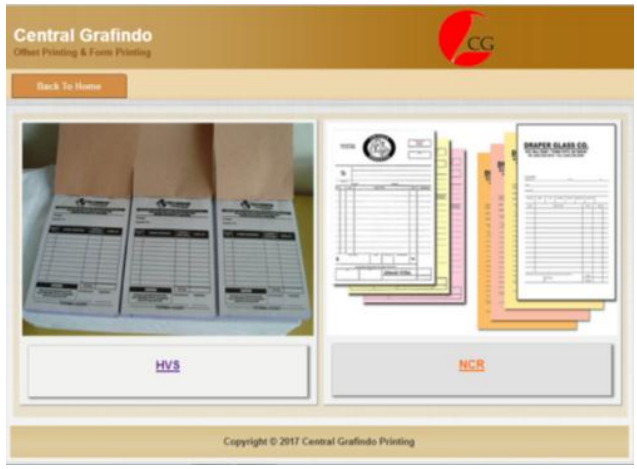

Gambar 3. Form NCR

Form NCR berisi tentang jenis cetakan yang berbentuk carbonize yang dimana jenis cetakan tersebut dapat tembus ke rangkapan selanjutnya.

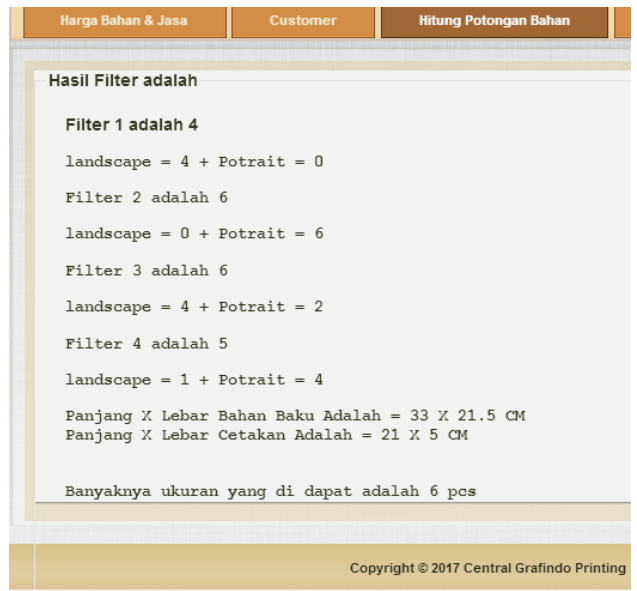

Gambar 4. Hasil Perbandingan Bahan

Edy Andersen, Halim Agung 
Setelah memilih jenis form maka akan di hadapkan kepada pengumpulan jenis bahan dan ukuran bahan cetakan customer, maka akan dilakukan penyaringan yang terdiri dalam 4 tahapan yang dimana nilai terbesar akan di ambil sebagai nilai untuk tahapan selanjutnya.

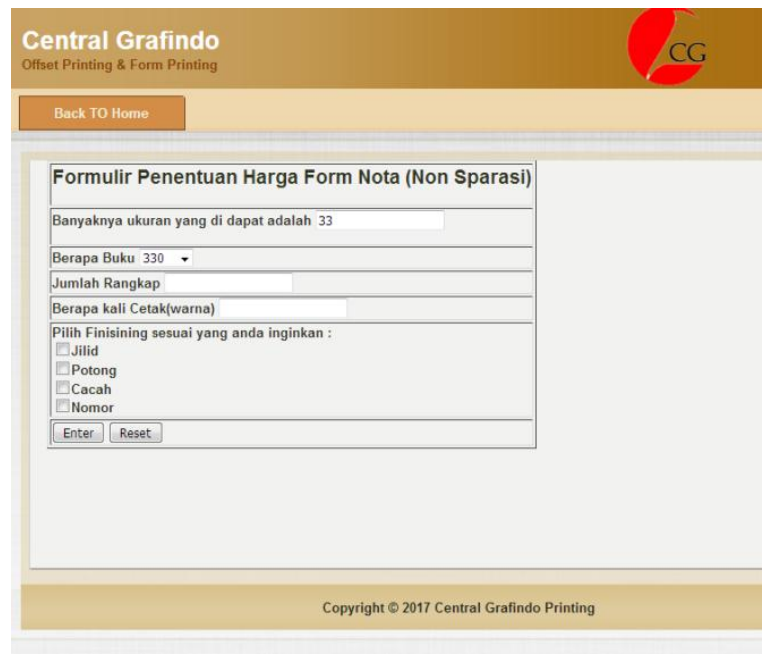

Gambar 5. Spesifikasi Pengerjaan

Setelah mendapatkan perhitungan nilai ukuran terbesar. Maka pada form ini akan dilakukan pengumpulan informasi sesuai dengan kebutuhan cetakan user dan akan dihitung dengan rumus yang ada sehingga akan terbentuk nilai harga jual.

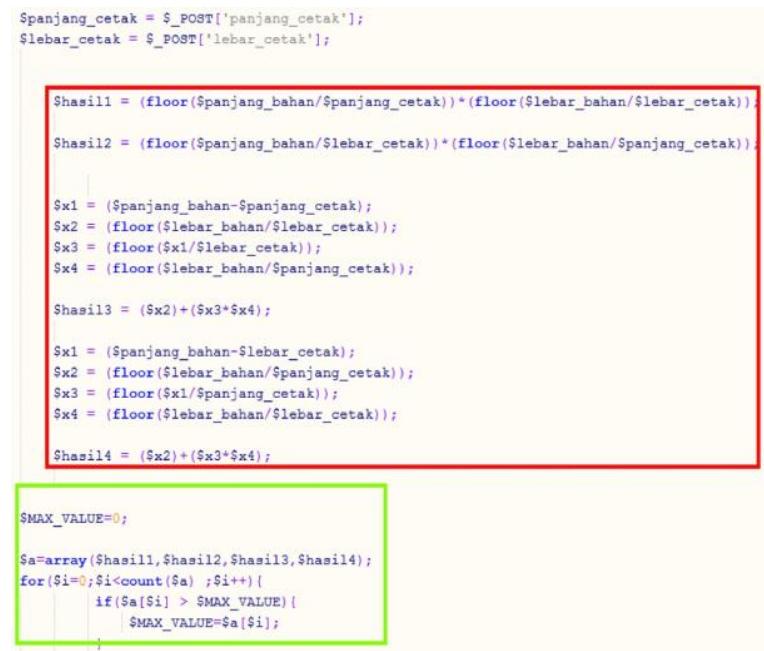

\section{Gambar 6. Proses Filter Ukuran dan Filter Nilai Paling Tinggi}

Pada Gambar 5 mengambarkan seluruh proses filter (kotak yang berwarna merah) yang di bagi menjadi beberapa bagian dengan kondisi filter yang berbeda satu sama lain. Sehingga akan di hasilkan 4 filter berbeda yang dimana akan di ambil nilai yang paling tertinggi (kotak yang berwarna hijau) sehingga nilai tersebut dapat di gunakan untuk melanjutkan perhitungan selanjutnya.

Proses yang dilakukan sebagai berikut:

1. Filter $1=$ membandingkan dengan menggunakan pembagian normal terhadap field sesamanya.

2. Filter $2=$ membandingkan dengan menggunakan pembagian normal terhadap field lawannya.

3. Filter $3=$ dalam proses filter ini agak rumit dimana akan dilakukan 4 kali saring yang secara umum dilakukan terhadap field sesamanya dengan menggunakan rotasi pada beberapa bagian tertentu.

4. Filter $4=$ dalam proses filter ini sama sulitnya dengan filter ke 3 dimana akan dilakukan 4 kali saring yang secara umum dilakukan terhadap field lawannya dengan menggunakan rotasi pada beberapa bagian tertentu.

5. Filter terakhir (garis warna hijau pada gambar 6) dilakukan penyaringan terhadap 4 hasil filter diatas yang dimana akan dipilih sebagai nilai yang paling besar atau bila nilai ke 4 hasil filter sama maka akan di pilih sebagai nilai sembarangan karena di anggap semua nilai sama.

Sebagai contoh jika user ingin mencetak Nota untuk menjalankan pencatatan di toko kelontongnya. Namun mendapat kendala karena tidak mengetahui cara perhitungan untuk mendapat nilai area cetak optimum dan ketersediaan bahan yang ada sehingga user menyediakan berbagai bahan baku cetakan yaitu bahan berukuran folio $(33 \mathrm{~cm} * 21.5 \mathrm{~cm})$, kemudian nota yang biasanya dipakai di toko kelontong ternyata ukurannya adalah $15 \mathrm{~cm} * 8 \mathrm{~cm}$.

Maka nilai optimum area cetak yang akan di dapat dijawab dalam beberapa filter (semua hasil di bulatkan ke bawah):

1. (Panjang bahan baku / panjang cetakan) * (lebar bahan baku / lebar cetakan $)=(33 / 15) *(21,5 / 8)$ $=2 * 2=4$ Pcs

2. (Panjang bahan baku / lebar cetakan) * (lebar bahan baku / Panjang cetakan $)=(33 / 8) *$ $(21,5 / 15)==4 * 1=4$ Pcs 
3. (lebar bahan baku / lebar cetakan) + ( ((Panjang bahan baku - panjang cetakan) / lebar cetakan) * $($ lebar bahan baku/panjang cetakan $))=(21,5 / 8)+$ $(((33-15) / 8) *(21,5 / 15))=2+(18 / 8) *(1)=2$ $+(2 * 1)=2+2=4$ Pcs

4. (lebar bahan baku / Panjang cetakan) + ( ((Panjang bahan baku - lebar cetakan) / panjang cetakan) * (lebar bahan baku/lebar cetakan $)$ ) = $(21,5 / 15)+(((33-8) / 15) *(21,5 / 8))=1+$ $(15 / 8) *(2)=1+(15 / 8) *(2)=1+(1 * 2)=3$ Pcs

5. Setelah di dapat masing-masing hasil filter maka di lakukan di filter terhadap ke 4 hasil tersebut untuk mendapat nilai paling maximum. Jadi jawaban untuk soal di atas adalah 4 Pcs

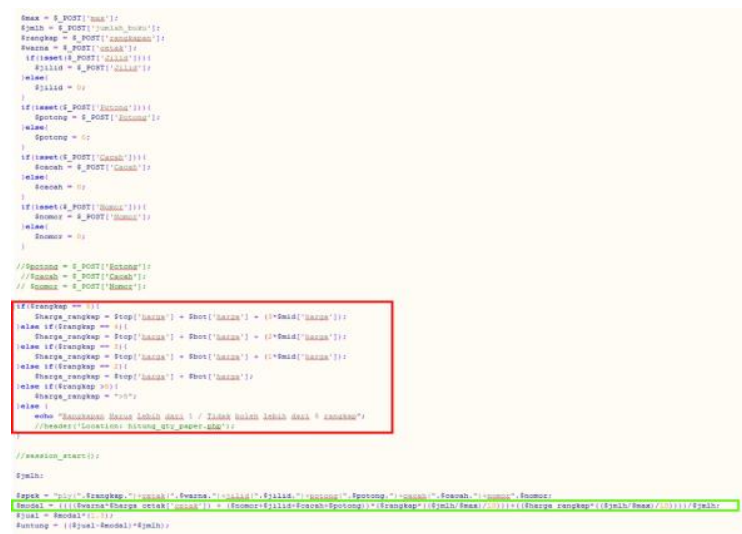

\section{Gambar 7. Proses Perhitungan Harga Bahan dan Perhitungan Harga Jual}

Pada garis merah pada gambar 7 mengambarkan seluruh alur untuk menghitung nilai dari bahan yang di butuhkan (terutama harga akhir) dalam proses pengerjaan suatu project/request (hanya berfokus pada bahan baku). Di samping itu terdapat pula garis hijau yang dimana dilakukan untuk melakukan perhitungan antara bahan baku dan jasa pengerjaan yang dimana akan di hasilkan sebuah nilai harga yang siap untuk dijual/di ajukan.
1. Pada gambar 7 yang garis berwarna merah dilakukan tahapan filter yang dimana untuk menghitung harga dari bahan baku yang user butuhkan. Dengan cara membandingkan poiint akhir dan point awal yang terdiri hanya 1 dan point tengah akan di sesuaikan dengan kebutuhan rangkapan yang dibutuhkan user namun hanya dibatasi 5 rangkap secara keseluruhan.

2. Proses penghitungan seluruh biaya pengerjaan dan bahan baku yang di total dan di bagi dengan jumlah buku yang di butuhkan user sehingga akan di dapatkan nilai modal.

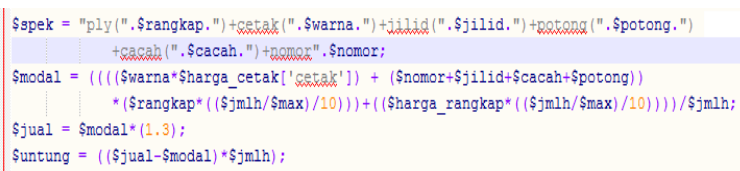

Gambar 8. Kode Proses Perhitungan Harga Bahan dan Perhitungan Harga Jual

Pada tahapan sebelumnya data record akan di simpan kedalam table record yang akan otomatis memberi nilai sendiri pada Id_record di dalam table record, kemudian setelah melakukan input form maka secara otomatis akan mendapat nilai dari table record terakhir sehingga tabel biodata dan tabel record memiliki hubungan.

Kemudian untuk membuktikan metode Branch \& Bound dapat berfungsi dengan baik pada aplikasi optimasi bahan cetakan maka dilakukan pengujian. Pengujian algoritma dilakukan dengan membandingkan nilai-nilai yang ada terhadap kondisi atau 4 filter yang ada. Hasil pengujian ini akan di bandingkan antar metode Branch \& Bound dengan perhitungan secara manual. Berikut 25 dari 50 pengujian yang dilakukan pada penelitian ini yang dapat dilihat pada tabel 1 .

Proses yang dilakukan adalah sebagai berikut:

Tabel 1. Tabel Pengujian Metode Branch \& Bound

\begin{tabular}{|c|r|r|r|r|r|}
\hline Pengujian & panjang & lebar & Hasil aplikasi sendiri & Perhitungan manual & Match \\
\hline & & & Filter $1=1$ & Test $1=1$ & \\
& \multirow{2}{*}{33} & \multirow{2}{*}{21.5} & Filter $2=0$ & Test $2=0$ & \\
& & & Filter $3=1$ & Test $3=1$ & \\
& & Filter $4=0$ & Test $4=0$ & \\
\hline & & & Filter $1=4$ & Test $1=4$ & \\
& \multirow{2}{*}{21} & \multirow{2}{*}{5} & Filter $2=6$ & Test $2=6$ & \\
& & & Filter $3=6$ & Test $3=6$ & \\
& & Filter $4=5$ & Test $4=5$ & \\
\hline
\end{tabular}

Edy Andersen, Halim Agung 


\begin{tabular}{|c|c|c|c|c|c|}
\hline Pengujian & panjang & lebar & Hasil aplikasi sendiri & Perhitungan manual & Match \\
\hline 3 & 21 & 10 & $\begin{aligned} & \text { Filter } 1=2 \\
& \text { Filter } 2=3 \\
& \text { Filter } 3=3 \\
& \text { Filter } 4=3\end{aligned}$ & $\begin{aligned} \text { Test } 1 & =2 \\
\text { Test } 2 & =3 \\
\text { Test } 3 & =3 \\
\text { Test } 4 & =3\end{aligned}$ & $\sqrt{ }$ \\
\hline 4 & 21 & 15 & $\begin{array}{l}\text { Filter } 1=1 \\
\text { Filter } 2=2 \\
\text { Filter } 3=1 \\
\text { Filter } 4=1\end{array}$ & $\begin{array}{l}\text { Test } 1=1 \\
\text { Test } 2=2 \\
\text { Test } 3=1 \\
\text { Test } 4=1\end{array}$ & $\sqrt{ }$ \\
\hline 5 & 21 & 20 & $\begin{array}{l}\text { Filter } 1=1 \\
\text { Filter } 2=1 \\
\text { Filter } 3=1 \\
\text { Filter } 4=1\end{array}$ & $\begin{array}{l}\text { Test } 1=1 \\
\text { Test } 2=1 \\
\text { Test } 3=1 \\
\text { Test } 4=1\end{array}$ & $\sqrt{ }$ \\
\hline 6 & 21 & 25 & $\begin{array}{l}\text { Filter } 1=0 \\
\text { Filter } 2=1 \\
\text { Filter } 3=0 \\
\text { Filter } 4=1\end{array}$ & $\begin{array}{l}\text { Test } 1=0 \\
\text { Test } 2=1 \\
\text { Test } 3=0 \\
\text { Test } 4=1\end{array}$ & $\sqrt{ }$ \\
\hline 7 & 21 & 30 & $\begin{array}{l}\text { Filter } 1=0 \\
\text { Filter } 2=1 \\
\text { Filter } 3=0 \\
\text { Filter } 4=1\end{array}$ & $\begin{array}{l}\text { Test } 1=0 \\
\text { Test } 2=1 \\
\text { Test } 3=0 \\
\text { Test } 4=1\end{array}$ & $\sqrt{ }$ \\
\hline 8 & 15 & 6 & $\begin{array}{l}\text { Filter } 1=6 \\
\text { Filter } 2=5 \\
\text { Filter } 3=6 \\
\text { Filter } 4=4\end{array}$ & $\begin{array}{l}\text { Test } 1=6 \\
\text { Test } 2=5 \\
\text { Test } 3=6 \\
\text { Test } 4=4\end{array}$ & $\sqrt{ }$ \\
\hline 9 & 15 & 9 & $\begin{array}{l}\text { Filter } 1=4 \\
\text { Filter } 2=3 \\
\text { Filter } 3=4 \\
\text { Filter } 4=3\end{array}$ & $\begin{array}{l}\text { Test } 1=4 \\
\text { Test } 2=3 \\
\text { Test } 3=4 \\
\text { Test } 4=3\end{array}$ & $\sqrt{ }$ \\
\hline 10 & 15 & 13 & $\begin{array}{l}\text { Filter } 1=2 \\
\text { Filter } 2=2 \\
\text { Filter } 3=2 \\
\text { Filter } 4=2\end{array}$ & $\begin{array}{l}\text { Test } 1=2 \\
\text { Test } 2=2 \\
\text { Test } 3=2 \\
\text { Test } 4=2\end{array}$ & $\sqrt{ }$ \\
\hline 11 & 15 & 16 & $\begin{array}{l}\text { Filter } 1=2 \\
\text { Filter } 2=2 \\
\text { Filter } 3=2 \\
\text { Filter } 4=2\end{array}$ & $\begin{array}{l}\text { Test } 1=2 \\
\text { Test } 2=2 \\
\text { Test } 3=2 \\
\text { Test } 4=2\end{array}$ & $\sqrt{ }$ \\
\hline 12 & 15 & 28 & $\begin{array}{l}\text { Filter } 1=0 \\
\text { Filter } 2=1 \\
\text { Filter } 3=0 \\
\text { Filter } 4=1\end{array}$ & $\begin{array}{l}\text { Test } 1=0 \\
\text { Test } 2=1 \\
\text { Test } 3=0 \\
\text { Test } 4=1\end{array}$ & $\sqrt{ }$ \\
\hline 13 & 10 & 8 & $\begin{array}{l}\text { Filter } 1=6 \\
\text { Filter } 2=8 \\
\text { Filter } 3=6 \\
\text { Filter } 4=6\end{array}$ & $\begin{array}{l}\text { Test } 1=6 \\
\text { Test } 2=8 \\
\text { Test } 3=6 \\
\text { Test } 4=6\end{array}$ & $\sqrt{ }$ \\
\hline 14 & 10 & 21 & $\begin{array}{l}\text { Filter } 1=3 \\
\text { Filter } 2=2 \\
\text { Filter } 3=3 \\
\text { Filter } 4=3\end{array}$ & $\begin{aligned} \text { Test } 1 & =3 \\
\text { Test } 2 & =2 \\
\text { Test } 3 & =3 \\
\text { Test } 4 & =3\end{aligned}$ & $\sqrt{ }$ \\
\hline 15 & 10 & 16 & $\begin{array}{l}\text { Filter } 1=3 \\
\text { Filter } 2=4 \\
\text { Filter } 3=3 \\
\text { Filter } 4=3\end{array}$ & $\begin{array}{l}\text { Test } 1=3 \\
\text { Test } 2=4 \\
\text { Test } 3=3 \\
\text { Test } 4=3\end{array}$ & $\sqrt{ }$ \\
\hline 16 & 10 & 33 & $\begin{array}{l}\text { Filter } 1=0 \\
\text { Filter } 2=2 \\
\text { Filter } 3=0 \\
\text { Filter } 4=2\end{array}$ & $\begin{array}{l}\text { Test } 1=0 \\
\text { Test } 2=2 \\
\text { Test } 3=0 \\
\text { Test } 4=2\end{array}$ & $\sqrt{ }$ \\
\hline 17 & 8 & 31 & $\begin{array}{l}\text { Filter } 1=0 \\
\text { Filter } 2=2 \\
\text { Filter } 3=0 \\
\text { Filter } 4=2\end{array}$ & $\begin{array}{l}\text { Test } 1=0 \\
\text { Test } 2=2 \\
\text { Test } 3=0 \\
\text { Test } 4=2\end{array}$ & $\sqrt{ }$ \\
\hline 18 & 8 & 5 & $\begin{array}{l}\text { Filter } 1=16 \\
\text { Filter } 2=12 \\
\text { Filter } 3=14\end{array}$ & $\begin{array}{l}\text { Test } 1=16 \\
\text { Test } 2=12 \\
\text { Test } 3=14\end{array}$ & $\sqrt{ }$ \\
\hline
\end{tabular}

Edy Andersen, Halim Agung 


\begin{tabular}{|c|c|c|c|c|c|}
\hline Pengujian & panjang & lebar & Hasil aplikasi sendiri & Perhitungan manual & Match \\
\hline & & & Filter $4=14$ & Test $4=14$ & \\
\hline 19 & 8 & 14 & $\begin{array}{l}\text { Filter } 1=4 \\
\text { Filter } 2=4 \\
\text { Filter } 3=3 \\
\text { Filter } 4=4\end{array}$ & $\begin{aligned} & \text { Test } 1=4 \\
& \text { Test } 2=4 \\
& \text { Test } 3=3 \\
& \text { Test } 4=4\end{aligned}$ & $\sqrt{ }$ \\
\hline 20 & 8 & 21 & $\begin{array}{l}\text { Filter } 1=4 \\
\text { Filter } 2=2 \\
\text { Filter } 3=3 \\
\text { Filter } 4=3\end{array}$ & $\begin{array}{l}\text { Test } 1=4 \\
\text { Test } 2=2 \\
\text { Test } 3=3 \\
\text { Test } 4=3\end{array}$ & $\sqrt{ }$ \\
\hline 21 & 8 & 28 & $\begin{array}{l}\text { Filter } 1=0 \\
\text { Filter } 2=2 \\
\text { Filter } 3=0 \\
\text { Filter } 4=2\end{array}$ & $\begin{array}{l}\text { Test } 1=0 \\
\text { Test } 2=2 \\
\text { Test } 3=0 \\
\text { Test } 4=2\end{array}$ & $\sqrt{ }$ \\
\hline 22 & 5 & 5 & $\begin{array}{l}\text { Filter } 1=24 \\
\text { Filter } 2=24 \\
\text { Filter } 3=24 \\
\text { Filter } 4=24\end{array}$ & $\begin{array}{l}\text { Test } 1=24 \\
\text { Test } 2=24 \\
\text { Test } 3=24 \\
\text { Test } 4=24\end{array}$ & $\sqrt{ }$ \\
\hline 23 & 5 & 10 & $\begin{array}{l}\text { Filter } 1=12 \\
\text { Filter } 2=12 \\
\text { Filter } 3=10 \\
\text { Filter } 4=12\end{array}$ & $\begin{array}{l}\text { Test } 1=12 \\
\text { Test } 2=12 \\
\text { Test } 3=10 \\
\text { Test } 4=12\end{array}$ & $\sqrt{ }$ \\
\hline 24 & 5 & 17 & $\begin{array}{l}\text { Filter } 1=6 \\
\text { Filter } 2=4 \\
\text { Filter } 3=5 \\
\text { Filter } 4=7\end{array}$ & $\begin{array}{l}\text { Test } 1=6 \\
\text { Test } 2=4 \\
\text { Test } 3=5 \\
\text { Test } 4=7\end{array}$ & $\sqrt{ }$ \\
\hline 25 & 5 & 20 & $\begin{array}{l}\text { Filter } 1=6 \\
\text { Filter } 2=4 \\
\text { Filter } 3=5 \\
\text { Filter } 4=6\end{array}$ & $\begin{array}{l}\text { Test } 1=6 \\
\text { Test } 2=4 \\
\text { Test } 3=5 \\
\text { Test } 4=6\end{array}$ & $\sqrt{ }$ \\
\hline
\end{tabular}

\section{KESIMPUlan dan SARAN}

Dari hasil penelitian diperoleh kesimpulan bahwa pemilihan metode Branch \& Bound dapat di implementasikan dengan baik dalam proses penentuan optimasi area cetak, user dapat mengetahui jenis posisi landscape \& portrait pada optimasi yang dipakai oleh sistem dan dengan adanya aplikasi ini di harapkan user akan sangat terbantu dalam penentuan optimasi area cetak dan penentuan harga sehingga dapat menghemat efisiensi waktu dan meminimalisir kesalahan human error dan telah terbukti pada pengujian yang dilakukan sebelumnya dengan persentase $100 \%$ dari 50 pengujian.

Untuk penelitian berikutnya yang dapat dikembangkan adalah mengembangkan sistem yang ada, baik di sisi keamanan maupun penyajian yang lebih baik

\section{REFERENSI}

Angeline. Iryanto. Tarigan, Gim. (2014), Penerapan metode branch and bound dalam menentukan jumlah produksi optimum pada cv.xyz, Saintia Matematika, pp 137-145.

Arief, M.Rudianto. (2011), Pemrograman Web Dinamis Menggunakan Php dan Mysql, ANDI, Yogyakarta.

Bassil, Youssef, (2012), A Simulation Model for the Waterfall Software Development Life Cycle, International Journal of Engineering \& Technology (iJET), Vol.2. No.5.

Fathansyah. (2012), Basis Data, Informatika Bandung, Bandung.

Fitriadi. Sri, DewiSusanti. Salam, Nur. (2010), Penggunaan Metode Branch \& Bound untuk menyelesaikan masalah penugasan pada kasus penyusunan jaringan komunikasi, Matematika Murni dan Terapan, Vol. 4, pp $42-56$

Frengki. (2014), Pembuatan Program Pembelajaran Integer Programming Metode Branch and Bound, Ilmiah Mahasiswa Universitas Surabaya, Vol.3.

Edy Andersen, Halim Agung 
Kadir, Abdul. (2013), Pemrograman Database MySQL Untuk Pemula, Mediakom, Yogyakarta.

Mangngenre, Saiful. Rapi, Amrin. Flannery, Wendy (2014), Penjadwalan produksi dengan metode Branch \& Bound pada pt. XYZ, BKSTI IPUL Makasar.

Nugroho, Adi. (2004), Pemrograman Berorientasi Objek, Informatika, Bandung.

Nur, E. Hayati. (2010), Aplikasi algoritma branch and bound untuk menyelesaikan integer programing, Dinamika Teknik, Vol. 4, pp 13-23.

Pressman, S. Roger. (2015). E-book Software Engineering: a Practitioner's Approach. Seventh Edition.

Rayina, Windi Rosa. Suhartono. Arif, Helmie Wibawa. (2012), Penentuan jalur terpendek pada pelayanan agen travel khusus pengantaran wilayah semarang berbasis SIG dengan algoritma branch and bound, Jurnal Masyarakat Informatika, Vol 4, No.7.

Retnawati, Yayuk. Hayaty, Nurul. Suswaini, Eka. (2012), Optimasi produk dan keuntungan pada industri kerupuk dengan metode Linier programing simpleks dan Branch and Bound CV. KYRIA REZEKI, Vol.X, No.1.

Riyani, Windi Rosa. (2013), Penentuan Jalur Terpendek pada Pelayanan Agen Travel Khusus Pengantaran Wilayah Semarang Berbasis SIG dengan Algoritma Branch and Bound, Jurnal Masyarakat Informatika, Semarang.

Sumarminingsih, Eni. Ajeng, Yuhendra Alannuariputri. (2013), Integer programing dengan pendekatan metode branch and bound dan metode cutting plane untuk optimasi kombinasi produk (Studi Kasus pada Perusahaan "Diva" Sanitary, Sidoarjo), Vol 1, No 2.

Suryawan, Gede. Ketut, Ni TariTastrawati. Sari, Kartika. (2016), Penerapan Branch and Bound algorithm dalam optimalisasi produksi roti, E-Jurnal Matematika, Vol. 5 (4), pp 148-155.

Tri, Arum Utami. (2013), Penerapan model integer linier programing (metode branch \& bound dan metode cutting plane) dan analisis titik IMPAS (BEP) multi produk guna mengoptimalkan jumlah produk, Yogyakarta 